NBER WORKING PAPER SERIES

\title{
INVESTMENT, FINANCIAL FACTORS AND CASH FLOW: \\ EVIDENCE FROM UK PANEL DATA
}

\author{
Michael Devereux
}

Fabio Schiantarelli

Working Paper No. 3116

\author{
NATIONAL BUREAU OF ECONOMIC RESEARCH \\ 1050 Massachusetts Avenue \\ Cambridge, MA 02138 \\ September 1989
}

\begin{abstract}
is is a revised version of a paper prepared for the conference "Information, ipital Markets, and Investment" held at the National Bureau of Economic search, Cambridge, May 1989. The results presented here form part of the search carried out at the Institute of Fiscal Studies, London, on the impact : corporate taxes, which is financially supported by the ESRC under grant 10222009. The authors are grateful to the following for helpful comments: W. Blunde11, S.R. Bond, R.G. Hubbard, F. Hayashi, F. Huizinga, K. Lang, J.K. ickie-Mason, C. Megir, J. Poterba, A. Weiss and participants at the NBER inference. Errors remain their own. This paper is part of NBER's research ogram in Financial Markets and Monetary Economics. Any opinions expressed e those of the authors not those of the National Bureau of Economic Research.
\end{abstract}




\title{
NBER Working Paper \#3116 \\ September 1989
}

\section{INVESTMENT, FINANCIAL FACTORS AND CASH FLOW: EVIDENCE FROM UK PANEL DATA}

\begin{abstract}
In this paper we provide some econometric evidence on the impact of financial factors like cash flow, debt and stock measures of liquidity on the investment decisions of U. K. firms. These variables are introduced via an extension of the $Q$ model of investment which explicitly includes agency/financial distress costs. We discuss if the significance of cash flow may be due to the fact that it proxies for output or because it is a better measure of market fundamentals than $Q$. Moreover we investigate if the effect of financial factors varies across different types of firms, according to size, age, and type of industry (growing and declining). We analise the determinants of the magnitude of the cash flow effect and explain why caution must be exercised in attributing inter-firm differences only to differences in the importance of agency or financial distress costs.
\end{abstract}

Michael Devereux Institute for Fiscal studies 180/182 Tottenham Court Road London, W1P 9LE England (01) $636-3784$
Fabio Schiantarel1i Department of Economics Boston University 270 Bay State Road Boston, MA 02215 (617) 353-4885 


\section{Introduction}

Most empirical models of company investment rely on the assumption of perfect capital markets. In a vorld without taxes, one implication of this assumption is that firms are indifferent to funding their nvestment programmes from internal or external funds. However, there is a rapidly growing body of iterature examining the possible existence of imperfections in capital markets and their effects on firm's inancial and real decisions. In this paper we provide some econometric evidence on the impact of inancial factors like cash flow, debt and stock measures of liquidity on the investment decisions of UK inms. These variables are introduced via an extension of the $Q$ model of investment which explicitly includes agency costs. We discuss if the significance of cash flow may be due to the fact that it proxies for output or because it is a better measure of market fundamentals than $Q$. Moreover we investigate if the effect of financial factors varies across different types of firm. The cross-sectional variation of the impact on investment of flow and stock measures of liquidity has been analysed also by Fazzari et al (1988) and by Gertler and Hubbard (1988) for US firms and by Hoshi et al (1988) for Japanese firms. The former studies distinguish between firms according to their divided payment behaviour, while the latter classify firms according to $i . .2$ strength of their institutional relationships with banks. Instead, we group observations according to firm size, age and type of industry (growing and declining). The empirical importance of this breakdown is a natural subject of investigation and moreover allows us to minimise the problems of endogenous selection. In the theoretical section we outline a simple model that illustrates how cash flow can be introduced in $Q$ models. We discuss the determinants of the size of the cash flow effect and explain why caution must be exercised in attributing inter-firm differences only to differences in the importance of agency or financial distress costs.

In section 1 we briefly review recent contributions to the literature on credit market imperfections, and in section 2 we show how features appearing in these models might be expected to influence investment decisions. Section 3 develops a simple extension of the investment model with adjustment costs which explicitly allows for agency costs of external finance. Section 4 describes the behaviour and performance of a sample of $720 \mathrm{UK}$ manufacturing firms, split by size and age, and section 5 presents some 
econometric results, obtained using instrumental variable, which indicate that financial factors, principi in the form of lagged cash flow, do have an independent effect on investment. Section 6 briefly concludes.

\section{The Cost of External Finance}

During the last few years there has been a renewed interest in understanding the relationship betwee investment and financing decisions, both at the theoretical and empirical level. The common theme underlying the various contributions is the lack of perfect substitutability between inside and outside financing. The existence of differential information and incentive problems make external finance mor. costly than internal finance. In this setting the availability of intemally generated funds and/or of asst that can be used as collateral may have an effect on investment decisions.

Let us briefly review the disadvantages and benefits of external finance. Starting with debt finance, th are different reasons why there may be a conflict between shareholders and debtholders, giving rise $t$ agency costs of debt. Jensen and Meckling (1976) suggest that stockbolders will have an incentive to engage in projects that are too risky and so increase the possibility of financial distress and bankrupt If successful, the payoff to the owners of the firm is large. If unsuccessful, the limited liability provisi of debt contracts implies that the creditors bear most of the cost. Myers (1977) suggests that if the firm is partly debt-financed, it may underinvest in the sense that it foregoes projects with a positive 1 present value. This problem is particularly severe when assets in place are a small proportion of the total value of the firm. Other areas of conflict between bondholders and shareholders are representec by the claim dilution resulting from the issue of additional debt and by the possibility that the firm $\mathrm{v}$ pay out excessive dividends financed by reduced investment.

Since potential creditors are assumed to understand the incentives facing stockholders and are aware the risk of bankruptcy when loans are negotiated, ultimately the owner will bear the consequences of these agency problems in terms of a higher cost of debt. With asymmetric information about borrowe quality, rationing may also occur (See Jaffe and Russell, 1976, Stiglitz and Weiss, 1981). As a way to control the conflict between bondholders and shareholders and to minimise the agency cost of debt, 
bond covenants are observed, limiting the discretionary action of the owners regarding dividends, future debt issues, and maintenance of working capital (Smith and Warner, 1979). Debt covenants usually contain a maximum limit on the amount of dividends that can be paid out which depends positively upon accumulated eamings. Restrictions on the minimum value of the ratio between tangible assets and debt, working capital and debt and, finally, between interest payments and cash flow are also common. The greater is the amount of debt in the firm's capital structure, the more severe the incentive problems become, and the more likely it is that the firm will face financial distress and ultimately bankruptcy. Because of the less favourable terms on which debt can be obtained and because of the cost associated with tighter monitoring and bonding activities, agency costs are therefore likely to be increasing in the level of debt. On the other hand it is likely that such costs are a decreasing function of the level of past and present earnings and of assets, particularly if liquid in nature, that can be used as collateral.

While agency costs make debt less attractive, the tax deductibility of interest payments make it more attractive. In the absence of such costs, debt is preferred to retentions if $(1-m) /(1-z)>1-t$, where $m$ is the marginal personal tax rate on interest income, $z$ the tax rate on capital gains and $t$ the corporate tax rate (King, 1977). In the UK this inequality is satisfied for most investors ${ }^{1}$.

New share issues may be disadvantageous because of transaction costs, tax reasons or asymmetric information. Informal evidence on transactions costs in the UK suggests that there are large fixed costs in issuing new equity ${ }^{2}$. The tax dis/advantage of new share issues relative to retentions in a classical system of company taxation depends upon the relationship between personal tax rates on dividends, $m$, and capital gains, $z$. If $m$ is greater than $z$, as it is usually the case, new equity issues are relatively more expensive (see, for example, King, 1977). In an imputation system, like the one in existence in the UK since 1973, the situation is more complex. New share issues are a cheaper source of finance for a

1 However, the possibility of negative profit, combined with corporate tax asymmetries, reduces the effective corporate tax rate because there may not exist taxable profits against which to offset interest payment. This reduces the tax advantage of debt (see DeAngelo and Masulis, 1980, Auerbach, 1986 and Mayer, 1986).

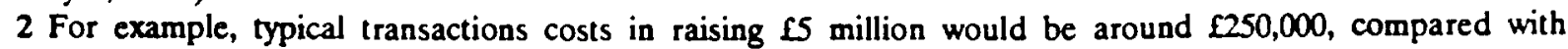
only $\mathfrak{E} 500,000$ for raising $\mathfrak{E} 50$ million. 
full tax paying firm if $(1-m) /((1-z)(1-c))>1$, where $c$ is the rate of imputation. This condition * be satisfied for institutional investors for whom $m=z=0$ and for other investors with a low marginal 1 rate on dividends ${ }^{3}$.

Finally, new share issues may be more costly because of asymmetric information. Myers and Majluf (1984) suggest that, if managers have inside information, it may happen that the latter is so favourabli that management, acting in the interest of old shareholders, will not issue new shares because they perceive them as being underpriced. Investors will therefore interpret the decision to issue new shares as a bad signal. In this case new equity finance can only be obtained at a premium, because of the adverse selection problem.

Up to this point in the discussion we have implicitly assumed that management acts in the interest of sharebolders. Allowing for the possible divergence of interest between managers and outside sharebolders provides an additional rationale for the disadvantage of external finance. If managers hav a less than $100 \%$ ownership stake in the company, they will be encouraged to use a greater than optimal amount of firms resources in the form of perquisites (Jensen and Meckling, 1976). Such activities can be monitored by the outside shareholders, but such monitoring is costly and the insiders will ultimately bear the cost in terms of a reduced price that prospective outside shareholders are willing to pay for a stake in the firm. This consideration suggests that the cost of outside financing is related to the stake of insiders and to the dispersion of outside ownership.

\section{Financial Factors and Investment Decisions}

What is the effect of credit availability, cash flow and collateralizable assets on investment decisions? The literature on this issue has been conducted in the context of models with different structures

3 The existence of a high allowance for capital gains results in a zero marginal tax rate for investors earning less than about $\$ 6000$ per year in the form of capital gains. One should in addition consider the possibility that firms may not be able to offset their advance corporation tax against the mainstrea corporation tax. This implies that the effective rate of imputation is smaller than the statutory rate, making new share issues less attractive (Keen and Schiantarelli, 1988). 
oncerning information and technology. One group of papers adds financial considerations to standard ivestment models based on the assumption of convex adjustment costs, usually estimated usually in ıeir $\mathbf{Q}$ form. For example, credit rationing with an exogenously given ceiling can be easily added to $Q$ todels. If there are tax advantages to debt, firms will borrow up to capacity. Under the standard ssumptions, (perfect competition, constant returns to scale, a single quasi-fixed factor) marginal $Q$ will ontinue to equal average $Q$, with the caveat that the present value of the interest payments net of new ebt issued should be added to the market value of shares in defining average $Q$. The present value of rese flows can be approximated by the current value of the stock of debt. One could also assume that re maximum amount of debt is a fixed proportion of the capital stock (Summers, 1981) with basically re same result.

Iternatively one could include in the objective function an additional cost term, increasing in the level f debt, that summarises the agency/financial distress cost of debt, as in Chirinko (1987) ${ }^{4}$. In this case. n internal solution for debt can be obtained. If the agency cost of debt is linear homogeneous in its rguments and the change (as opposed to the level) of debt does not enter the agency cost function, rarginal $Q$ again equals average $Q$. If the change in debt does appear in the agency cost function and ze latter is not linear homogeneous, the difference between marginal and average $Q$ depends upon the resent and future values of the change and level of debt (Chirinko, 1987).

Then personal taxation is taken into account and if capital gains are taxed less heavily than dividends, ne can distinguish between three financing regimes ${ }^{5}$. In regime 1 , investment can be financed at the targin by retentions, positive dividends are paid and no new shares are issued. In regime 3 , the firm sues new shares and pays no dividend. In the intermediate case, regime 2 , both dividends and new sare issues are zero and the marginal source of finance is debt. A relationship between investment and ux-adjusted average $Q$, can be derived only in the regimes 1 and 3 . In the last regime no such slationship exists and investment equals cash flow plus new debt issued. In this context, an increase in ash flow makes the probability that investment is financed at the margin by retentions more likely and

See also Steigum (1983) and Bernstein and Nadiri (1986) $u$, :e the cost of borrowing is made an icreasing function of the debt/equity ratio.

Edwards and Keen (1985) discuss what happens when dividends are tax favoured and a maximum mit is imposed on their distributions, as is the case in the UK. 
this can be shown to increase investment (Hayashi, 1985). However, conditional on Q, cash flow does not bave an additional explanatory power in the regimes 1 and 3. In regime 2 , increases in cash flow (and debt) translate into a one to one increase in investment and $Q$ does not matter.

Fazzari et al. (1988) extend Q models by including a premium for issuing new shares, based on the adverse selection argument put forward by Myers and Majluf (1984). The existence of this premium increases the cost differential between internal finance and new equity and it increases the likelibood that the firm will find itself at the point of discontinuity where all profits are retained, no dividends paid and firm's future prospects are not good enough to induce it to issue new shares. For those fin $Q$ does not matter, while cash flow does matter.

In another group of papers the role and consequences for investment of informational imperfections : more closely analysed. In this context the amount of net assets that can be used as collateral is a determinant of the agency cost of external finance and has an effect of investment. The particular informational asymmetry and the details about technology differ across papers, but the common themt is that insiders have less incentive to cheat and more incentive to act in the interest of outside investors when their stake in the project is greater (see the contributions by Bernanke and Gertler, 1989, Gertler, 1988 and Gertler and Hubbard, 1988). The link between firm's value and the fraction c entrepreneur wealth invested in the project is also emphasised by Leland and Pyle (1977). Since borrower's net worth is likely to be procyclical, incentive problems may be particularly severe in a recession. This may lead to an asymmetric effect of financial variables on investment during the business cycle.

The existence of informational asymmetries that restricts the firms' ability to raise external equity play a crucial role also in the paper by Greenwald and Stiglitz (1988). They show that production and investment depends upon their equity position. Since there is only limited access to equity markets, th main way to change firms' equity is to accumulate cash flow, net of financial obligations. All these models imply that an increase in collateralizable net worth may stimulate investment. The more precis. modelling of the informational asymmetries and of the possibility of bankruptcy is clearly a strength o these models. However, they do not yield an investment equation that explains how financial factors a expectations about firms' prospects jointly determine investment. 


\section{From Theory to Testing}

The empirical importance of financial variables, in particular cash flow and stock measures of liquid assets, characterises many econometric studies of investment based on firm by firm data (see Fazzari et al., 1988, and Gertler and Hubbard, 1988, for the US, Hayashi and Inoue, 1988, and Hoshi et al., 1988, for Japan and Blundell et al., 1988, for the UK). Most of the testing has been conducted in the context of $Q$ models in which average $Q$ is used to control for the investment opportunities open to firms. Fazzari et al. and Gertler and Hubbard analyse the cross sectional variation in the importance of financial factors by classifying firms according to their dividend payout behaviour, while Hoshi et al. make a distinction between firms with and without strong links with a single bank.

We discuss the role of financial factors in the context of a simple variant of a $Q$ model of investment. The model includes on the cost side a term, A, representing agency/financial distress costs which is a function of the stock of debt, B, the capital stock, $K$, the stock of liquid assets $L$, and cash flow, X. Debt and liquid assets are chosen endogenously, together with investment and new share issues. On the basis of the arguments of the pro - ous section, agency costs are an increasing function of debt and a decreasing function of cash flow and of liquid assets. The agency cost function is expected to vary for firms in different age and size classes and in different industries. The reasons why this may be the case are summarised in section 4. Moreover there is a premium that must be paid for issuing new shares. This way of summarising informational asymmetries and the risk of bankruptcy is obviously ad hoc. It is adopted here to provide some unifying principle to our discussion and to our empirical testing and to make clear the implicit assumptions underlying the type of equations that have been used so far to test for the importance of financial factors in equations containing average $Q$. In particular, we want to specify a model that is consistent with the fact that cash flow may matter (albeit differently) for all firms, and not only for those that have used up all retentions and are not issuing any new shares. Under the assumption of perfect competition, linear homogeneity of the production, adjustment and agency cost function, the marginal condition for investment, I, implies that when positive dividends are paid (see appendix): 


$$
\left(\frac{I}{K}\right)_{t}=\frac{1}{b\left(1-A_{X}\right)}\left\{\frac{\lambda_{t}^{K} / Y}{(1-\tau) p_{t}^{\prime}}-\frac{p_{t}}{(1-\tau) p_{t}^{\prime}}\right\}
$$

where $A_{X}$ denotes the partial derivative of the agency cost function with respect to cash flow, $\lambda^{K_{1}}$ is the marginal shadow value of capital, $p_{t}^{y}$ the output price, $p_{t}$ the investment price, all in period $t, \tau$ the corporate tax rate and $Y$ the tax discrimination parameter between dividends and retentions, equal to $(1-m) /((1-z)(1-c))$. The linear homogeneity assumption, although not necessarily realistic, allows one to show that the following relationship bolds between the marginal and average values of the capital stock:

$\lambda_{t}^{\kappa} K_{t-1}(1-\delta)+\lambda_{t}^{B} B_{t}+\lambda_{t}^{L} L_{t}=1 \cdot\left(1+\frac{R}{1-i}\right)$

where $V_{t}$ is the market value of firms' shares at the beginning of period $t, R$ is the market return on equity and the $\lambda_{s}$ are the shadow values of the state variables. If the firm is on its optimal path, it is possible to show that $\lambda_{1}^{B_{1}}=-\left(Y+\mu^{D_{1}}\right)(1+R /(1-z))$ where $\mu^{D_{1}}$ is the multiplier on the non-negativity condition for dividends. Similarly $\lambda L_{t}=\left(Y+h^{D}\right)(1+R /(1-z))$. If positive dividends are paid, as is almost always the case in our sample, the multiplier, $\mu^{D}$, is zero. Using this result in (2) and taking a first order approximation of (1) around sample averages or steady state values we can write:

$\left(\frac{I}{K}\right)_{t}=\beta_{0}+\beta_{1} Q_{t}+\beta_{2}\left(\frac{X}{p K^{*}}\right)_{t}+\beta_{3}\left(\frac{B}{p K}\right)_{t}+\beta_{4}\left(\frac{L}{p K}\right)_{t}$

where $\mathrm{I} / \mathrm{K}$ denotes investment expenditures and

$Q_{t}=\frac{\left(V_{t} / Y+B_{t}-L_{t}\right)\left(1+\frac{R}{1-z}\right)}{(1-\delta) K_{t-1}(1-\tau) p_{t}^{y}}-\frac{p_{t}}{(1-\tau) p_{t}^{y}}$

The coefficients, denoting sample averages or steady state values by bars, are: 
$\beta_{1}=\frac{1}{b\left(1-A_{x}\right)} ; \beta_{2}=\frac{\left(\frac{l}{\kappa}\right) \bar{A}_{x \cdot x / \kappa}}{1-\bar{A}_{x}} ; \beta_{3}=\frac{\left(\frac{l}{\kappa}\right) \bar{A}_{x, B / K}}{1-\bar{A}_{x}} ; \beta_{+}=\frac{\left(\frac{l}{\kappa}\right) \bar{A}_{x, L / K}}{1-\bar{A}_{x}}$

where subscripts again denote partial derivatives.

This equation suggests that the coefficient in front of average $Q$ reflects both the adjustment cost parameter $b$ and the derivative of the agency cost function with respect to cash flow. The coefficient of cash flow is positive if $A_{X X / K}>0$, as is reasonable to assume (ie. increasing cash flow reduces agency costs at a decreasing rate). The coefficient increases with the average investment rate. It also depends upon average cash flow/capital, debt/capital, liquid assets/capital. Similar comments apply to the coefficients of $B / K$ and $L / K$, the signs of which depend on the cross partial derivatives of $A$. If the agency cost function is additively separable in the pairs $(X, K),(B, K)$ and $(L, K)$, the last two regressors can be omitted and the coefficient of $X / K$ depends only upon the average cash flow to capital ratio (in addition to the investment rate). Unless more specific assumptions are made about the functional form of $\mathrm{A}$ little can be said a priori on its effect on the size of the coefficient and this is a source of ambiguity in forecasting the expected strength of the effect of cash flow, debt and liquid assets on investment for different rpes of firms. Aside from this ambiguity, we allow the agency cost function to be displaced upward or downward by a multiplicative constant which is specific for each group of firms and therefore varies according to size, age and sector. An increase in the constant unambiguously increases the coefficient of cash flow, debt and liquid assets.

There are several reasons why the agency cost function may vary across firms. First, it might be expected that young and small firms may be at a disadvantage, ceteris paribus, when raising external finance. Younger firms are likely to be a riskier prospect since the shorter track record makes it more difficult to judge their quality. Moreover smaller firms often tend to be less diversified, to display greater earnings volatility, and to be more prone to bankruptcy (Titman and Wessels, 1988). However, there are also reasons why it might be the case that incentive problems are more severe for firms in which insiders own a smaller proportion of the firm and outside ownership is more dispersed. Since size may proxy for ownership structure, there is some ambiguity in assessing the effect of size on 
agency cost. Finally, it is intuitively more probable that firms in declining sectors may face financial distress. The second hand market for capital goods is likely to be less active, the liquidation value of assets to be smaller and, therefore, the cost of financial trouble greater in this case.

We have assumed so far that positive dividends are being paid, because this is what our data suggests happens most of the time. In this case the first order condition on new shares issues implies that $Y-1-\omega_{1}+\mu_{1}^{N}=0$, where $\omega t$ is the marginal adverse selection premium firms have to pay when issuing new shares, and $\mu^{N}$ is the non-negativity constraint on new equity issues. If $\omega t$ is independer of $V^{N}$, as in Fazzari et al. (1988), then we need to assume that $Y$ is less than $1+\omega t$, otherwise it would pay to finance continuous new dividend distributions by issuing new shares. If the above condition holds, firms will not issue new shares and pay dividends at the same time. In order to provide a satisfactory rationale for an internal solution for dividends and new share issues, it would be necessary to provide an analysis of the signalling role of dividends and of the possibility of tax exhaustion, but this goes beyond the purpose of this paper. The specification of $Q$ models when the various asymmetries of the tax schedule are explicitly modelled is contained in Devereux at al. (1989) where it is shown that an internal solution for dividends and new share issues can be obtained becaus the possibility of tax exhaustion reduces the effective value of $Y$. Altematively it must be assumed that personal tax rates vary across investors and that the condition $Y=1+\omega$, determines the marginal investor in the case of an internal solution.

\section{Intra-Firm Differences in Financing, Investment and Profitability in the UK}

In this section we discuss how financing, investment, profitability and other characteristics vary across different types of firms according to size, age and sector. The results presented here are based on a sample of 720 firms in the UK manufacturing sector over the period 1969-1986, quoted on the Londor Stock Exchange. Because of births and deaths and an increase in the number of firms available in 197 the number of records on each firm varies between 4 and 18; only 89 firms existed for the entire sample period. Data have been obtained from two sources. Accounting data on each firm has been provided by Datastream, and market valuations have been taken from the London Share Price 
Database. These two sources have been merged for each firm in each year to provide the data used in this paper ${ }^{6}$. These firms account for approximately 65 per cent of total investment in manufacturing between 1977 and 1985. The construction of the variables follows that in Blundell et al. (1989). Company investment includes direct purchase of new fixed assets and those acquired through acquisitions. The firm's market value is an average for the threee month's prior to each accounting year. Replacement cost estimates of the capital stock are estimated using the perpetual inventory method?

The discussion above implied that there are several reasons why one might expect the location of the agency cost function to differ across firms. Given its location, the expectation of the relative effect of financial factors on investment would also depend on their relative investment rates, and their cash flow, debt and other liquid assets relative to their capital stock. In this section we present some evidence on the relative sizes of these ratios and more generally on firms' characteristics according to size, age and whether they operate in a growing or declining sector.

It is also worth commenting briefly on the difference between these splits (by size, age and sector) and that used by Fazzari et al. (1988). Fazzari et al. split their sample of firms according to their dividend payout ratios. This was an attempt to identify those firms which were likely to pay no dividends and at the same time did not find it profitable to issue new shares. In the US, this may be reasonable (Fazzari et al. show that, among their group of firms having a low payout rate, that dividends are paid only $33 \%$ of the time). However, in the UK the vast majority of firms pay dividends every year while some firms also raise external equity finance fairly frequently. Without explicitly modelling why firms pay dividends - for example, because of a possible signalling role (see for instance John and Williams (1985), Ambarish et al. (1987) and Edwards (1987) for a critical discussion) - it is not clear which firms are constrained by their earnings and which are not. For example, if cutting dividends is taken to be a negative signal, firms which have paid high dividends in the past will be forced 10 maintain a high

6 The LSPD data is needed to calculate Tobin's Q.

7 Further details are available from the authors on request. 
dividend strategy. Alternatively, following Easterbrook (1984) and Rozeff (1982), it might be argued the firms with a more widespread ownership are required to pay a higher dividend because this implicitly forces them to submit to scrutiny from the market when they raise external funds.

In Table 1 we present some summary statistics when each observation on each firm is classified into one of three size categories according to the real value of the capital stock (1980 prices) at the beginning of the preceding period $\left(\mathrm{pK}_{\mathrm{t}-2}\right)$. The observation is classified as small if $\mathrm{pK}_{\mathrm{t}-2}$ is less than E6 million, medium if $\mathrm{pK}_{\mathrm{t}-2}$ is between 26 million and 150 million, and large if $\mathrm{pK}_{1-2}$ is above ESO million. Note that as firm grows, it may move from one group to the other. As explained in the next section, we split the sample according to the size of $\mathrm{pK}_{1-2}$ in order to minimise problems of endogenous selection in estimation ${ }^{89}$. The table indicates that investment and cash flow, each as a percentage of the end of period capital stock, decrease with size. This is particularly true of cash flow with small firms generating a return of $18 \%$ compared to only $11 \%$ for large firms. Ceteris paribus, th existence of higher cash flows for small firms makes it less likely that they will face financial constraints. The dividend payout ratio is higher for larger firms, although this appears to be mainly du to the fact that depreciation (the difference between cash flow and profit) represents a higher proportion of cash flow for large firms; the average dividend to cash flow ratio is remarkably constant across the three size categories. The frequency with which dividends are paid increases with size, but even for small firms however, the average dividend payout ratio is approximately $34 \%$ and dividends at paid $89 \%$ of the time.

Prima facie evidence that internal sources of finance are preferred to external sources is represented b the fact that investment is financed mainly through retentions, which constitute about $67 \%$ of the total sources of funds. Perhaps surprisingly, the proportion of funds raised from retentions by large firms is almost identical to that raised by small firms. New equity varies between 12 and $15 \%$ of total new

8 Splitting by payout behaviour is more open to criticism from this point of view.

9 In order to allow for any distortion to these results arising from measurement error in $K$, a similar split was performed using the real value of sales two periods earlier as a measure of size. The results were very similar. 


\section{Table 1 Split by Size}

Case $1 \quad \mathrm{pK}_{\mathrm{t}-2}<\mathrm{f6m}$

Case $2 \quad \mathrm{fbm}_{\mathrm{m}}<\mathrm{pK}_{\mathrm{t}-2}<\mathfrak{2 5 0 \mathrm { m }}$

Case $3 \mathrm{pK}_{-2}>\mathrm{LSOm}$

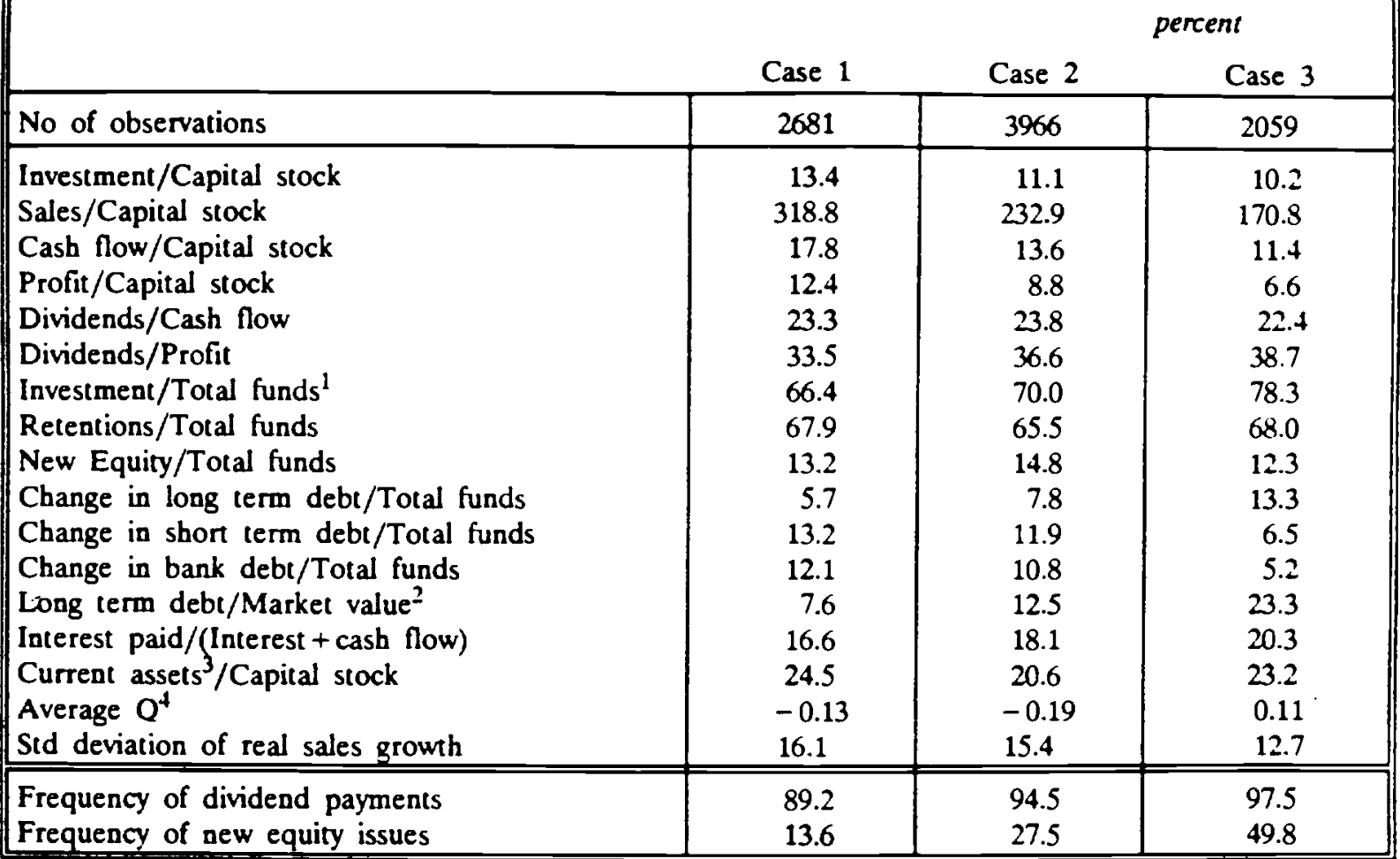

Notes:

1. Total funds are the sum of retentions, new equity and the change in long term and short term debt.

2. "Market value" is taken as the market value of equity plus the book value of debt.

3. Current assets comprise inventories and work in progress, financial investments, the stock of cash and trade debtors less trade creditors and other short term liabilities (excluding short term debt).

4. $O$ is defined in equation (4). $V_{t}$ is measured at the beginning of the period. 
funds ${ }^{10}$. The frequency of new share issues increases with size. The lower frequency of new equity issues for small firms is consistent with the observation that flotation and underwriting costs are an decreasing function of the value of the issue.

Long term debt represents a small percentage of investment finance especially for smaller firms. This suggests that it is expensive for small firms to rely on market debt. Note, however, that the percentage of new finance derived from short term debt (with maturity of less than one year) is greater for smaller firms. The vast majority of their sbort term debt is provided by banks. This indicates that the difficulty of borrowing in the open market may be partly relieved by the ability to borrow from institutions that can more easily monitor the borrower tbrough a continuing relationship. It is not clear however, that the duration of bank debt matches the requirements imposed by investment projects that will provide a return over a long period of time.

A final piece of interesting evidence from Table 1 is the standard deviation of real sales growth falls with size although this effect is not very large. The slightly higher figure for small firms may be reflected in the relatively high ratio of current assets to the capital stock, in that such firms may find $i$ useful to maintain a sizeable reserve of liquid assets in order to buffer the volatility of sales revenues and to avoid being forced to borrow on unfavourable terms. Moreover, this ratio is one of the indices commonly used by lenders to judge the credit worthiness of potential borrowers. Other indicators of th ability to meet financial obligations is the ratio between interest payments and cash flow, whicb is smaller for smaller firms. By presenting a healthy liquid asset position firms may be able to reduce the cost of borrowing.

Table 2 presents some independent evidence on the degree to which financial factors are perceived to influence the investment decision of different sizes of firms. The figures are taken from the quarterly survey of UK manufacturing industry conducted by the Confederation of British Industry. It indicates that over the period 1981 to 1986 virtually a third of the respondents cited some financial factor as constraining their investment (although it is hard to distinguish the three questions related to financial factors). The most striking feature of the table is, however, the proportion of the largest firms which

10 Mayer (1988) claims that the proportion of funds raised from new share issues is somewhat lower, although our figures are in line with official statistics (DTI Business Monitor, MA3). 
cited "shortage of internal finance" as a significant constraint on their investment. While the sample of firms in this category is low", this does suggest that very large firms may face financial constraints. The table suggests, however, that slightly less large firms (in the third category) face somewhat lower financial constraints.

\section{Table 2 Evidence from CBI Industrial Trends Survey of UK Manufacturing companies}

Average response to the question: "What factors are likely to limit (wholly or partly) your capital expenditure authorisations over the next 12 months?" over the period 1981 to 1986 (24 quarterly surveys)

\begin{tabular}{|c|c|c|c|c|c|}
\hline \multicolumn{6}{|c|}{ Percent } \\
\hline & \multirow[b]{2}{*}{$\begin{array}{l}\text { Whole } \\
\text { sample }\end{array}$} & \multicolumn{4}{|c|}{ Size by number of employees } \\
\hline & & $0-199$ & $200-499$ & $500-4999$ & $\begin{array}{l}\text { more than } \\
5000\end{array}$ \\
\hline Inadequate net return on proposed investment & 39.5 & 26.3 & 38.5 & 41.7 & 46.5 \\
\hline Shortage of internal finance & 21.2 & 15.4 & 15.5 & 8.5 & 29.2 \\
\hline Inability to raise external finance & 2.6 & 3.0 & 2.3 & 2.1 & 2.9 \\
\hline Cost of finance & 8.5 & 10.6 & 8.5 & 8.0 & 8.4 \\
\hline Uncertainty about demand & 46.3 & 56.7 & 52.8 & 48.2 & 36.9 \\
\hline Shortage of labour (inc. man \& tech staff) & 3.1 & 3.7 & 3.5 & 2.4 & 3.1 \\
\hline Other & 2.3 & 2.0 & 2.8 & 2.4 & 2.4 \\
\hline N/A & 12.2 & 14.2 & 9.6 & 10.3 & 13.4 \\
\hline
\end{tabular}

Another dimension that has a potential bearing on investment and financing decisions, especially in the presence of asymmetric information, is the firm's age. Although we do not have exact information on each firm's age, we do know when firms went public. In Table 3, we distinguish between observations on firms that have been quoted for at least 12 years and observations on firms younger than 12 years. In this table we examine only small and medium-sized firms (ie. $\mathrm{pK}_{\mathrm{t-2}}$ less than E50 million). Since

11 Between 25 and 60 out of a sample of around 1250 . 
larger firms are almost exclusively more than $\mathbf{1 2}$ years since their first quotation, they would all fall into the "old" category. By concentrating on the remainder, we consider firms which, apart from age, are more nearly alike.

\section{Table 3 Split by Size and Age}

Case 1 pK-2 < E50m; less than 12 years since first quotation

Case 2 pK $1-2<550 \mathrm{~m}$; more than 12 years since first quotation

\begin{tabular}{||l|c|c|}
\hline \multicolumn{2}{|c|}{ Case 1 } & Case 2 \\
\hline No of observations & 773 & 5874 \\
\hline Investment/Capital stock & 14.4 & 11.0 \\
Sales/Capital stock & 282.5 & 238.0 \\
Cash flow/Capital stock & 18.0 & 13.6 \\
Profit/Capital stock & 12.3 & 8.9 \\
Dividends/Cash flow & 23.6 & 23.7 \\
Dividends/Profit & 34.5 & 36.4 \\
Investment/Total funds & 72.3 & 69.2 \\
Retentions/Total funds & 69.0 & 65.5 \\
New Equity/Total funds & 15.3 & 14.5 \\
Change in long term debt/Total funds & 5.9 & 7.7 \\
Change in short term debt/Total funds & 9.8 & 12.3 \\
Change in bank debt/Total funds & 9.3 & 11.1 \\
Long term debt/Market value & 10.1 & 12.2 \\
Interest paid/(nterest + cash flow) & 17.4 & 18.0 \\
Current assets/Capital stock & 13.2 & 21.8 \\
Average Q & 0.81 & -0.30 \\
Std deviation of real sales growth & 17.1 & 15.6 \\
\hline Frequency of dividend payments & 95.5 & 92.0 \\
Frequency of new equity issues & 24.1 & 21.6 \\
\hline
\end{tabular}

Notes:

1. See notes to Table 1.

Within this size category, new firms have a higher investment rate and cash flow. The payout ratio is fairly stable across the two categories. New firms have a higher use of retentions, and also derive a 
slightly larger fraction of new funds from new share issues. The higher profitability and investment of the new firms is reflected in a higher value of $Q$. There is little variation in the standard deviation of sales growth, thus suggesting that sales volatility does not depend to any great extent on firm age.

It was also suggested above that the location of the agency cost function, and hence the degree to which companies face financial constraints depends on the sector in which it is operating. We have therefore also considered the difference between companies in growing and declining sectors, this time conditioning on size by splitting the sample according to whether $\mathrm{pK}_{\mathrm{t}-2}$ is greater or less than $\mathbf{f 1 0}$ million. (The state of manufacturing industry in the UK in the 1970s and early 1980s was such that a majority of our sample of firms belonged to sectors which declined over the period considered). As might be expected, comparing firms of similar size, both investment and profitability is, on average. higher for firms in growing sectors. Again, however, the average dividend payout ratios are very similar across the different categories. Further, no clear pattern emerges conceming the use of different sources of finance, although small firms in growing industries make less use of retention finance (only $59 \%$ of total new funds).

\section{Empirical Results}

What does the empirical evidence say about the role of financial factors in investment decisions for $\mathrm{LK}_{\mathrm{K}}$ firms? We start our discussion from the results obtained from estimating equation (3) for the entire sample. We wish to allow for the possibility of time specific and firm specific effects. Introducing the subscript $i$ to distinguish companies, we therefore wish to estimate

$$
\left(\frac{l}{K}\right)_{u}=\beta_{0}+\beta_{1} Q_{u}+\beta_{2}\left(\frac{X}{p K}\right)_{t}+\beta_{3}\left(\frac{B}{p K}\right)_{i t}+\beta_{+}\left(\frac{L}{p K}\right)_{t}+\alpha_{t}+\alpha_{t}+t_{t}
$$

The stochastic term, $v_{i t}$, arises from disturbances to the adjustment cost function, as in the standard $Q$ model. There is nothing in the theory which restricts this term to be an innovation error, and indeed, related research estimating the $Q$ model on similar data has suggested that $v_{\text {it }}$ follows an AR(1) process (Blundell et al., 1988). To allow for this possibility, lagged values of the dependent variable and 
of each regressor are included in the equation (although we estimate the model without imposing the common factor restriction). The lagged values may, of course, also reflect the ambiguities involved in choosing the timing of the various variables.

The model has been estimated in first differences to allow for firm specific, time invariant effects ${ }^{12}$ and an instrumental variable procedure is used to allow for the endogeneity of the regressors. This endogeneity arises because current cash flow, debt, current assets, $Q$ and investment may all be simultaneously determined (although $Q$, unlike the other variables, is constructed by dating it at the beginning of the period). In addition, care must be taken to allow for the possibility of measurement error, particularly in $Q$. As well as contemporaneous values of these variables being invalid instruments, first-differencing introduces the correlation between, for example, $Q_{t-1}$ and $v_{t-1}$ into the equation. In the absence of serial correlation in $v_{i t}$, however, further lags of each of the regressors are valid instruments. Thus, in the third period, variables dated $t=1$ may be used as instruments in the differenced equation (as well as $Q_{i 2}$ if it is uncorrelated with $v_{i 2}$ ). Similarly, in the fourth period, variables dated $t=1$ and $t=2$ are valid instruments. Since this gives more instruments in later periods and since $v_{\text {it }}$ may be heteroscedastic across companies, we use an application of Hansen's (1982) generalised method of moments estimator. However, computing restrictions ${ }^{13}$ force us to restrict the instrument set. Below we denote the instrument set used in the form eg. $Q(n, m)$, where $n$ indicates that the latest lag used is dated $t-n$, and $m$ indicates the number of lags used ${ }^{14}$.

12 Related research (Blundell et al., 1989) has indicated that the presence of firm specific effects can lead to biased estimated coefficients when the model is estimated in its levels form. In addition, the presence of the lagged dependent variable in the more general equation makes the within-groups estimator inconsistent for dynamic models with small $T$ (Nickell, 1981).

13 We have used GAUSS 1986, version 1.49B, in which the instrument set must be restricted to 90 instruments. Thanks are due to Manuel Arellano and Stephen Bond for allowing the use of their GAUSS programs in this work.

14 For $m=1$, the GMM instrument set differs from simply using eg. $Q_{t-n}$ essentially by allowing the reduced form coefficient to vary over time. 
In column 1 of Table 4 we present the estimated coefficients for the equation containing, in addition to $\mathrm{Q}$ and lagged investment, both flow and stock measures of liquidity and the stock of debt ${ }^{15}$. Time fummies are included as regressors and instruments in all equations. The results suggest that contemporaneous $Q$ is a significant determinant of investment although, as in most other empirical studies, the size of its coefficient is small. Cash flow, especially dated $t-1$, plays an important role with a large coefficients. The coefficient on contemporaneous debt is negative and significant, as one would expect if an increase in cash flow decreases the marginal agency cost of debt, so that $A_{X . B / X}<0$ (see (5)). The stock of liquid assets does not play a significant role in this equation. Dropping liquid assets from the model in column 1 has very little effect on the other terms in the equation.

These results are generally robust to variations in the instrument set. The equation does not exhibit second order serial correlation (see the M2 statistic) which would invalidate the instrument set.

Moreover, the Sargan test of overidentifying restrictions suggests that the instruments are not correlated with the error term. If $Q_{t-1}$ is included in the instrument set. the coefficient on contemporaneous $Q$ falls, which is consistent with the possibility that downwards bias due to measurement error in $Q$ outweighs any upward bias due to the possible endogeneity of $Q^{16}$. This result is also found when the same comparison is made for the oher equations presented below, and so we generally exclude $Q_{1-1}$ from the instrument set.

The positive effect of the lagged investment rate and the negative coefficient on the lagged $Q$ term are consistent with an AR(1) error term in the underlying equation. However, the positive coefficients on both the cash flow terms is inconsistent with this explanation of the dynamic structure. (Replacing $(\mathrm{X} / \mathrm{pK})_{\mathrm{t}}$ with $(\mathrm{X} / \mathrm{pK})_{\mathrm{t}-2}$ provides a result consistent with the $\mathrm{AR}(1)$ process although this would imply

15 We have experimented with altemative empirical measures for gamma. The results are very similar whatever measure is used. The results are also not sensitive to the inclusion of the discount factor, $R$, in the definition of $Q_{t}$. In the tables we report the results obtained when gamma and the discount factor are set equal to one.

16 In principle, including $\mathrm{Q}_{1-2}$ in the instrument set may also introduce measurement error since it also appears as a regressor in the differenced equation, although in later tables the first-differenced $Q_{1-1}$ is omitted since it is not significant for subsamples of the data. This issue bas been explored in detail by Blundell et al (1989) on the same data set and our choice of instrument set is consistent with their results. 


\begin{tabular}{|c|c|c|c|}
\hline \multirow[t]{2}{*}{ Dependent Variable $\Delta\left(I / K^{\circ}\right)_{\text {e }}$} & \multicolumn{3}{|c|}{$\begin{array}{c}\text { Period } 1972-1986 \\
720 \text { companies } \\
6546 \text { observations } \\
\end{array}$} \\
\hline & 1 & 2 & $\underline{2}$ \\
\hline$\Delta(I / K)_{1-1}$ & $\begin{array}{r}0.1896 \\
(0.0306) \\
\end{array}$ & $\begin{array}{r}0.1896 \\
(0.0286) \\
\end{array}$ & $\begin{array}{r}0.1907 \\
(0.0284) \\
\end{array}$ \\
\hline$\Delta Q$ & $\begin{array}{r}0.0180 \\
(0.0051) \\
\end{array}$ & $\begin{array}{r}0.0166 \\
(0.0079) \\
\end{array}$ & $\begin{array}{r}0.0158 \\
(0.0074) \\
\end{array}$ \\
\hline$\Delta Q_{1-1}$ & $\begin{array}{r}-0.0044 \\
(0.0019) \\
\end{array}$ & $\begin{array}{r}-0.0039 \\
(0.0025) \\
\end{array}$ & $\begin{array}{l}-0.0036 \\
(0.0023) \\
\end{array}$ \\
\hline$\Delta(C F / p K)$ & $\begin{array}{r}0.1168 \\
(0.0788) \\
\end{array}$ & $\begin{array}{r}-0.0086 \\
(0.1494) \\
\end{array}$ & $\begin{array}{r}0.0481 \\
(0.1180) \\
\end{array}$ \\
\hline$J(C F / p K)_{t-1}$ & $\begin{array}{r}0.1584 \\
(0.0582) \\
\end{array}$ & $\begin{array}{r}0.2309 \\
(0.0894) \\
\end{array}$ & $\begin{array}{r}0.2179 \\
(0.0798) \\
\end{array}$ \\
\hline$J(B / p K)$, & $\begin{array}{c}-0.0772 \\
(0.0300) \\
\end{array}$ & - & - \\
\hline$J\left(B / p K^{-}\right)_{1-1}$ & $\begin{array}{r}0.0581 \\
(0.0418) \\
\end{array}$ & - & - \\
\hline$د(L / p K)$ & $\begin{array}{r}-0.0149 \\
(0.0130) \\
\end{array}$ & - & - \\
\hline$\Delta(L / p K)_{t-1}$ & $\begin{array}{r}0.0153 \\
(0.0138) \\
\end{array}$ & - & - \\
\hline$\Delta(Y / p K)_{t}$ & - & -1 & $\begin{array}{r}-0.0059 \\
(0.0043) \\
\end{array}$ \\
\hline$\Delta\left(Y^{\prime} / p K\right)_{t-1}$ & -1 & - & $\begin{array}{r}0.0023 \\
(0.0033) \\
\end{array}$ \\
\hline $\begin{array}{l}m 2 \\
\text { Sargan } \\
\text { W } \\
\end{array}$ & $\begin{array}{r}-1.26 \\
59.0(55) \\
52.1(15) \\
\end{array}$ & $\begin{array}{r}-1.17 \\
97.7(70) \\
49.5(15) \\
\end{array}$ & $\begin{array}{r}-1.21 \\
96.5(68) \\
51.1(15) \\
\end{array}$ \\
\hline Instruments & $\begin{array}{r}\mathrm{Q}(2,2), \mathrm{CF} / \mathrm{pK}(2,1) \\
\mathrm{B} / \mathrm{pK}(2,1) \\
\mathrm{I} / \mathrm{K}_{\mathrm{t}-2, \mathrm{I} / \mathrm{K}_{\mathrm{t}}-3,} \\
\mathrm{~L} / \mathrm{pK}_{\mathrm{t}-2, \mathrm{~L} / \mathrm{pK}_{\mathrm{t}}-3} \\
\end{array}$ & $\begin{array}{r}\mathrm{I} / \mathrm{K}(2,1), \mathrm{Q}(2,2) \\
\mathrm{CF} / \mathrm{pK}(2,1) \\
\mathrm{Y} / \mathrm{pK}(2,1)\end{array}$ & $\begin{array}{r}1 / \mathrm{K}(2,1), \mathrm{Q}(2,2) \\
\mathrm{CF} / \mathrm{pK}(2,1) \\
\mathrm{Y} / \mathrm{pK}(2,1)\end{array}$ \\
\hline
\end{tabular}


Notes

1. Time dummies are included in all equations.

2. Asymptotic standard errors are reported in parentheses. Standard errors and test statistics are asymptotically robust to heteroscedasticity across companies.

3. $\mathbf{m} 2$ is a test for second-order serial correlation in the residuals, asymptotically distributed as $N(0,1)$ under the null of no serial correlation. See Arellano and Bond (1988).

The Sargan statistic is a test of the over-identifying restrictions, asymptotically distributed as

4. $X^{2}(k)$

$W$ is a Wald test of the joint significance of the time dummies, asymptotically distributed as 5. $\mathrm{Y}^{2}(k)$ under the null of no significance.

6. The instrument sets are explained in the text.

that lagged cash flow, not current cash flow, should be in the specification in equation (3)). This suggests that the timing of the impact of cash flow in investment is more complex than suggested by the model in section 3. Intuitively, the significance of lagged cash flow may be explained if external investors may observe only cash flow in the previous period, or, more generally, may judge the firm's credit worthiness using a weighted average of past cash flows ${ }^{17}$.

In column 2 of Table 4 we explore what happens when debt is excluded from the model (debt is rarely significant in the subsamples of the data examined below, mainly due to the fact that less data is available). The positive effect of contemporaneous cash flow disappears in the absence of the negative effect of contemporaneous debt, while lagged cash flow becomes more important. The coefficient on current $Q$ falls slightly.

In Column 3 lagged and twice lagged output as a proportion of the replacement value of the apital stock is added to this specification (contemporaneous output is not significant). Their coefficients are neither individually nor jointly significant. However, note that the negative coefficient on current output is consistent with the presence of imperfect competition, which introduces an additional wedge between

17 This would require in the inclusion of $X_{t-1}$ and further lags in the agency cost function described in section 3 . 
marginal and average $Q$, which depends on the present value of current and future output ${ }^{18}$. The wedge captures the loss of monopoly profits due to the decrease in price associated with the additional output produced by new investment. Adding output to the equation to some extent proxies for the wedge, and therefore we would expect a negative coefficient ${ }^{19}$. We explore this issue further below for different subsamples of the data.

The presence of output in the equation bas little effect on the coefficient of lagged cash flow. Its renaaining significance suggests that even if cash flow is to some extent proxying for demand, this is not the main reason for its importance. The principal model investigated below is a parsimonious version of column 2 of Table 4, dropping lagged $Q$ and current cash flow (which are individually and jointly insignificant). The size and significance of the other variables is virtually unchanged when these two terms are omitted.

One reason for the significance of cash flow is that it may be a better proxy for market fundamentals than the market value of the firm and entrepreneurs may respond only to fundamentals (Blanchard et al., 1988). In this case one would expect that during periods of potential speculative bubbles or fads in the tock market, the coefficient for $Q$ and cash flow should be different, compared with other periods. In particular one may expect that $Q$ matters less relative to cash flow in such periods. It is obviously difficult to identify unambiguously when bubbles or fads caused share prices to be a poor reflection of fundamentals. During the years covered by our estimation, the years between 1981 and 1986 are

18 More precisely, omitting debt, liquid assets and taxes, it can be shown that

$$
\lambda_{t}^{k}=\frac{(1+R)\left\{V_{t}-\sum_{t=1}^{\infty} \frac{1}{\epsilon_{t+1}}(1+R)^{-1} p_{t-1}^{y} Y_{t+1}\right\}}{(1-\delta) K_{t-1}}
$$

where $\epsilon_{t+l}$ is the elasticity of demand.

19 However, if the equation is estimated in a quasi-differenced form as suggested by Schiantarelli and Georgoutsos (1988) and Galeotti and Schiantarelli (1988), the contemporaneous investment rate, given 'scaled' past investment should be positively related to $(\mathrm{Y} / \mathrm{K})_{\mathrm{t}-\mathrm{l}}$. When this variable is added to our specification alone, it is rarely significant. This issue deserves additional investigation. 
possible candidates; average price-earnings ratios have been consistently higher from 1981 onwards then over the previous 10 years. While this may, of course, simply reflect more optimistic expectations, this may also reflect the existence of a bubble.

We have therefore re-estimated the specification used below, for example in Table 5, allowing all of the slope coefficients to differ between the two subperiods. However, there is no strong evidence of a structural break. The Wald test statistic for the joint significance of the three additional terms (each variable interacted with a dummy equal to 1 for the period 1981 to 1986 and 0 otherwise) is 6.83 (compared with a critical value of 7.81 at the $5 \%$ significance level). In addition, the coefficient on lagged cash flow for the whole period was 0.2951 (with standard error 0.0462 ), while that for the additional variable lagged cash flow from 1981 to 1986 only was -0.0982 (with standard error of 0.0607 ). If $Q_{t-1}$ is included in the instrument set, the three additional terms become jointly significant (with a Wald statistic of 15.3). The same pattern arises for the cash flow terms, and additionally in this case, the coefficient on $Q$ from 1981 to 1986 only is positive and significant. Any support for a structural break which might be found in these results would therefore be in the opposite direction to what would be expected if cash flow were merely proxying for market fundamentals. Rather, it seems that in the relative boom years of the 1980s firms were simply less financially constrained and hence cash flow was less important. The asymmetric effect of cash flow on investment during booms and recessions is emphasised by Gertler and Hubbard (1988). Of course, it may be that cash flow proxies both for market fundamentals and financial constraints, but that the change in the latter dominate in the 1980s. This is an issue that deserves further investigation. However these initial results suggest that fads and bubbles are not the key explanation as to why cash flow is significantly related to investment. The arguments summarised in the previous section suggest that cash flow and other financial variables may have a differential impact across different types of firms. In Table 5 we present the results on the effect on cash flow for firms of three different sizes ("small", "medium" and "large"). We also consider "very large" firms (which are a subset of the group of "large" firms). Note that observations are classified according to the size of the capital stock at the end of time $\mathrm{t}-2, \mathrm{pK}_{1-2}$. Under the assumption that the error term in the levels equation is not serially correlated, $\mathrm{pK}_{\mathfrak{t}-2}$ is predetermined 


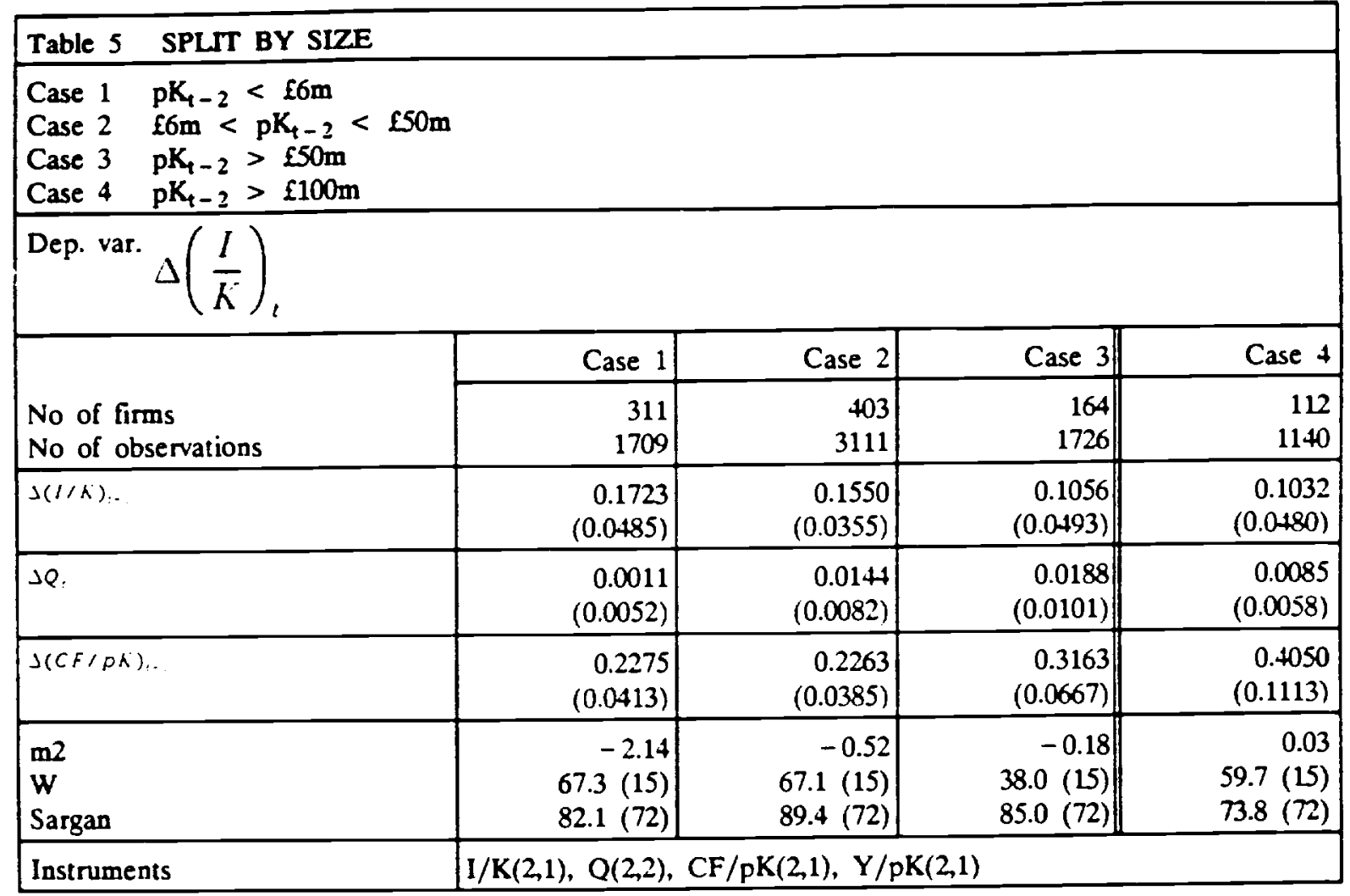

Notes

1. See notes to Table 4.

with respect to the error term in the differenced equation. Current assets were not significant when added to the various equations. In addition, current cash flow and further lags of cash flow and $Q$ were generally insignificant when added to the equations presented.

Consider, first, cases 1,2 and 3. The coefficient on cash flow is significant for all classes of firms. Perhaps surprisingly, it is greater for large firms, although there is not a statistically significant difference between the coefficients for large and small firms at normal significance levels (the t-statistic 
for the significance of the difference between the two coefficients is 1.13$)^{20}$. The coefficient and the significance of current $Q$ increases across the size categories; for small firms $Q$ appears to have no impact on investment, while for large firms, the coefficient on $Q$ is much greater. Given the increasing coefficient on cash flow as size increases, we also consider whether the impact of cash flow for large firms is dominated by very large firms. The results shown in case 4 show that this may be the case; although the coefficient on cash flow for very large firms is less precisely determined (due to fewer observations) the significance of the difference between it and that for small firms is slightly higher (with a t-statistic of 1.50 ).

These qualitative results are invariant to alternative instrument sets. However, the significance of both the $Q$ and cash flow does vary with the instrument set. In particular, if $Q_{1-1}$ is included in the instrument set, current $Q$ is statistically significant for medium, large and very large firms although the estimated coefficients are slightly lower. In addition, the differences between the cash flow coefficients are more significant (with t-statistics of 1.68 for the difference between small and large firms and 1.88 for the difference between small and very large firms).

With one main exception, adding other regressors has little impact on the coefficients and standard errors presented in Table 5. The exception occurs when current output is added to the model for large firms. The coefficient on current output for large firms is -0.0106 with standard error 0.0026 . Its negative sign is again consistent with the possibility that output is reflecting the existence of imperfect competition since large firms are more likely to be in a position to exploit the benefits of monopolistic competition. The coefficient on curent cash flow for large firms increases substantially when curent output is included, although it is less precisely estimated. Current debt also has a negative sign but is not significant when added to the models in Table 5. Adding debt tends to increase the difference in the coefficients on cash flow between case 1 and case 3 firms, although their standard errors also increase.

20 We need to test the hypothesis that the difference between the cash flow coefficients equals zero. On the assumption that the error terms are independent across the two categories, the appropriate standard error is simply the square root of the sum of the squares of the two standard errors on the two coefficients. This allows a simple t-test to be performed on the difference between the coefficients. 
In the context of the model sketched in the previous section, the size of the coefficient on cash flow for large firms cannot be accounted for by a higher investment rate of large firms (see (4)), because it is, in fact, lower. It could be explained by the lower cash flow/capital ratio that characterises larger firms, if the coefficient of cash flow decreases with this ratio. It is easy to find parameterisations of the agency cost function that yield this result ${ }^{21}$. This factor may be dominant since differences in the investment rate are not very large and neither is the difference in the riskiness as measured by the variance of sales. It is also possible that the differential according to size may capture industry effects. Finally, it is possible that, ceteris paribus, agency costs may be more severe when insiders effectively controlling the firm hold a lower fraction of the equity and/or outside equity holdings are more dispersed. Size may proxy for the effect of these factors on the severity of the incentive problems.

Two criticisms might be made with regard to splitting firms according to the replacement cost value of the capital stock two periods ago. One is that there may remain some endogeneity introduced by serial correlation in the error term (although we do not find such correlation). The second is that whatever effects size is proxying for, an alternative would be to split by the size of a firm relative to the size of otier firms in the industry in which that firm operates. Thus a "small" firm overall may seem larger relative to other firms in its own industry. To meet these possible criticisms, we first split firms according to their initial size (that is, their size when they first entered the database). Of course, this takes no account of the rate of growth of a firm since it entered the database, and possibly as a result, there is much less variation in the value of the cash flow coefficient between different size classes of firms measured by initial size. However, in Table 6, we present the results of splitting firms according to their initial size relative to that of other firms in their industry which are also in the database. Thus, case 1 firms are among the smallest 75\% of firms in their industry measured by initial size and case 2 firms are among the largest $25 \%$. It is clear from the table that the results concerning cash flow are

21 This would be the case, for example, if, ignoring liquid assets $A=\left\{-a(X / K)^{\alpha}+b(B / K)^{\beta}\right\} K^{-}$

where $0<\alpha<1$, or if $A=(K / K)^{\alpha}(B / K)^{\beta} K$

where $\alpha<0$. 
similar to those in Table 5 (indeed the size and significance of the difference across the two categories is greater in Table 6; the t-statistic on the difference between the two cash flow coefficients is 1.84). By contrast, however, $Q$ appears more important for the smaller firms. This latter result may be partly due to grouping together all "non-large" firms in the first column.

\section{Table 6 SPLTT BY INITIAL SIZE RELATIVE TO DISTRIBUTION OF INDUSTRY} INITIAL SIZE

Case $1 \mathrm{pK}_{0}$ within smallest $75 \%$ of firms in the same industry

Case $2 \mathrm{pK}_{0}$ within largest $25 \%$ of firms in the same industry

\begin{tabular}{|l|r|r|}
\hline Dep. var. $J\left(\frac{I}{K}\right)$, & \multicolumn{2}{|}{} \\
\hline & Case 1 & Case 2 \\
\cline { 2 - 3 } No of firms & 4530 & 2016 \\
No of observations & 541 & 179 \\
\hline$د(1 / K)$. & 0.1741 & 0.1782 \\
& $(0.0325)$ & $(0.0546)$ \\
\hline$د(Q)$, & 0.0130 & 0.0060 \\
& $(0.0082)$ & $(0.0032)$ \\
\hline$د(C F / \rho K)_{1-1}$ & 0.2303 & 0.3613 \\
& $(0.0293)$ & $(0.0648)$ \\
\hline m2 & -1.67 & -0.33 \\
$W$ & $96.9(15)$ & $38.5(15)$ \\
Sargan & $102.0(72)$ & $85.1(72)$ \\
\hline Instruments & $\mathrm{I} / \mathrm{K}(2,1), \mathrm{Q}(2,2), \mathrm{CF} / \mathrm{pK}(2,1), \mathrm{Y} / \mathrm{pK}(2,1)$ \\
\hline
\end{tabular}

Notes

1. See notes to Table 4.

While we do not have any data on ownership patterns, we can control for industry. An interesting distinction, as suggested above, is between growing and declining sectors. Table 7 contains the results of the size/sector split (using only two categories for size). Due to the small number of observations in some of the categories, parameters are estimated with less precision than in other tables. The perhaps surprising result from Table 7 is that the coefficient on cash flow is greater for firms operating in 
growing sectors. This is true even if the long run impact of cash flow is considered. This table also mirrors the result that cash flow is more important for large firms, with the largest coefficient being for large firms in growing sectors. This result is not sensitive to the instrument set used. One explanation for this effect may be that the lower investment rate of firms in declining sectors dominates empirically their lower cash flow and their higher agency costs which, ceteris paribus, would be expected to arise. The table indicates that the impact of $Q$ is mixed: among small firms it is more important for firms in declining sectors but among large firms it is more important for firms in growing sectors.

The final issue we wish to explore is the effect of age on the relevance of cash flow. In Table 8 we report the results obtained when, excluding large firms, we distinguish between firms that have been quoted for more or less than twelve years. Twelve years may seem rather long, but it is imposed by the necessity of having enough observations in the "new" firms category for the purposes of estimation. The results suggest that cash flow is somewhat more important for new firms, although the differences between the two categories are not large. Once again, it should be noted that the category of new firms is very small, and that the variables consequently tend to be less significant. 


\section{Table 7 SPLIT BY SIZE AND SECTOR}

Case $1 \quad \mathrm{pK}_{1-2}<$ f10m; growing sectors

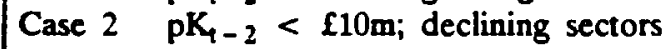

Case $3 \quad \mathrm{pK}_{-2}>\mathrm{E10m}$; growing sectors

Case $4 \quad \mathrm{pK}_{1-2}>$ E10m; declining sectors

Dep. var. $J\left(\frac{I}{K}\right)_{t}$

\begin{tabular}{|l|r|r|r|r|}
\hline \multirow{3}{*}{ No of firms } & Case 1 & Case 2 & Case 3 & Case 4 \\
\cline { 2 - 5 } No of observations & 157 & 298 & 132 & 279 \\
\hline$د(1 / K) \ldots$ & 859 & 1775 & 1356 & 2556 \\
\cline { 2 - 5 } & 0.2222 & 0.1246 & 0.0614 & 0.1149 \\
\hline$(Q)$ & $(0.0674)$ & $(0.0454)$ & $(0.0613)$ & $(0.0413)$ \\
\hline$د(C F / p K)$ & 0.0086 & 0.0142 & 0.0299 & 0.0061 \\
& $(0.0080)$ & $(0.0056)$ & $(0.0145)$ & $(0.0030)$ \\
\hline $\mathrm{m} 2$ & 0.2719 & 0.1786 & 0.3234 & 0.2055 \\
$W$ & $(0.0648)$ & $(0.0400)$ & $(0.0683)$ & $(0.0433)$ \\
Sargan & -3.05 & -1.24 & -0.66 & 0.02 \\
\hline Instruments & $39.8(15)$ & $55.8(15)$ & $30.9(15)$ & $48.5(15)$ \\
& $67.1(72)$ & $85.8(72)$ & $82.2(72)$ & $89.3(72)$ \\
\hline
\end{tabular}

Notes

1. See notes to Tables 4 and 5 .

2. Growing sectors are: chemicals and man-made fibres, electrical and instrument engineering and food, drink and tobacco. Declining sectors are: metals and metal goods, other minerals and mineral products, mechanical engineering, motor vehicles and parts and other transport equipment, textiles, clothing, leather and footwear and other industries. 


\section{Table 8 SPLIT BY SIZE AND AGE}

Case $1 \mathrm{pK}_{\mathrm{t}-2}<550 \mathrm{~m}$; less than 12 years since first quotation

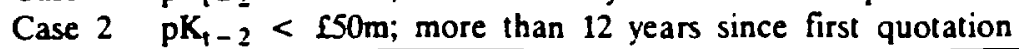

Dep. var.

$\Delta\left(\frac{I}{K}\right)$,

\begin{tabular}{|c|c|c|}
\hline & Case 1 & Case 2 \\
\hline $\begin{array}{l}\text { No of firms } \\
\text { No of observations }\end{array}$ & $\begin{array}{r}99 \\
450 \\
\end{array}$ & $\begin{array}{r}574 \\
4370 \\
\end{array}$ \\
\hline$S(H / K) \ldots$ & $\begin{array}{r}0.0935 \\
(0.0610)\end{array}$ & $\begin{array}{r}0.1939 \\
(0.0342) \\
\end{array}$ \\
\hline$J(Q)$. & $\begin{array}{r}0.0122 \\
(0.0099) \\
\end{array}$ & $\begin{array}{r}0.0095 \\
(0.0066) \\
\end{array}$ \\
\hline$\Delta(C F / P R) \ldots$ & $\begin{array}{r}0.2720 \\
(0.0662) \\
\end{array}$ & $\begin{array}{r}0.2242 \\
(0.0302) \\
\end{array}$ \\
\hline $\begin{array}{l}m^{2} \\
W^{2} \\
\text { Sargan }\end{array}$ & $\begin{array}{r}-1.57 \\
36.7(15) \\
48.3(44)\end{array}$ & $\begin{array}{r}-0.97 \\
88.4(15) \\
100.7(72) \\
\end{array}$ \\
\hline Instruments & $\begin{array}{r}(\mathrm{I} / \mathrm{K})_{\mathrm{t}-2,},(\mathrm{I} / \mathrm{K})_{1}-3 \\
\mathrm{Q}(2,1), \mathrm{CF} / \mathrm{pK}(2,1) \\
\mathrm{Y} / \mathrm{pK}(2,1)\end{array}$ & $\begin{array}{r}\mathrm{l} / \mathrm{K}(2,1), \mathrm{Q}(2,2), \\
\mathrm{CF} / \mathrm{pK}(2,1), \\
\mathrm{Y} / \mathrm{pK}(2,1)\end{array}$ \\
\hline
\end{tabular}

Notes

1. See notes to Tables 4 and 5 .

\section{Conclusions}

The results discussed in this paper suggest that in all cases cash flow is significantly associated with investment. Stock measures of liquidity do not play an important empirical role. The stock of debt does appear to have a negative impact on investment, although the significance of this term depends on the size of the sample. The performance of $Q$ is mixed. While it plays a significant role in the full sample, there are subsamples, typically of small firms, in which it does not appear to have an independent effect on investment. The results for the full sample over different time periods suggest that the 
significance of cash flow is not due solely to the fact that, in proxying for demand, it is a better measure of fundamentals than $Q$, nor simply that it contains new information not captured by beginning of period $Q$, although more research is needed on this issue.

Cash flow does appear to differ across firms in the magnitude of its impact on investment. In particular, it appears to play a more important role for large firms than for small firms. While this may be surprising at first sight, there are several reasons why this effect might be observed. For example, it may reflect the fact that large firms tend to have a lower relative cash flow. In addition, it may reflect the possibility that large firms have a more diverse ownership structure, which tends to increase agency costs. Given size, the effect of cash flow tends to be larger for firms in growing sectors, contrary to what one would expect since collateralizable net worth is likely to be larger in this case and the risk of bankruptcy lower. However, firms in growing sectors need to finance a higher rate of investment.

Finally, when firms are classified according to age, it appears that cash flow matters somewhat more for newer firms, as would be expected since information asymmetries are likely to be larger for such firms, and they need to finance a higher investment rate.

Our results suggest that capital market imperfections should be an important ingredient of any extension to or reformulation of the adjustment cost model of investment. However, the mixed performance of $Q$ suggests that such extensions should be pursued in future work 22 .

22 For example, see Chirinko (1984) and Hayashi and Inoue (1988) for Q models with multiple capital inputs, Galeotti and Schiantarelli (1988) for a Q model which with imperfect competition and labour as a quasi-fixed factor and Bond and Meghir (1989) for an adjustment cost model which avoids the use of stock market values and parameterisation of the gross production function. 
References

Ambarish. R., John. K. and J. Williams. 1987. 'Efficient signalling with dividends and investments', Joumal of Finance, 43.2:321-343.

Auerbach. A. J. 1986. 'The dynamic effects of tax law asymmetries', Review of Economic Studies, 53:205-225.

Bernanke. B. and M. Gertler. 1989. 'Agency costs, net worth and business fluctuations', American Economic Review, March, 79.1:31-41.

Bernstein. J. I. and M. I. Nadiri. 1986. 'Financing and investment in plant and equipment an research and development', in Prices, Competition and Equilibrium, M. H. Preston and R. E. Quandt, Philip and Allen.

Blanchard. O. J., Rhee. C. and L. H. Summers. 1988. 'The stock market, profit and investment', mimeo. Blundell. R., Bond. S. R. Devereux. M. P. and F. Schiantarelli. 1989. 'Does Q matter for investment? Some evidence from a panel of UK companies', Institute for Fiscal Studies, Revision of Discussion Paper, 87/12a.

Bond. S. R. and C. Meghir. 1989. 'Dynamic investment models and the firm's financial policy', mimeo, Institute for Fiscal Studies.

Chirinko. R. S. 1984. 'Investment, Tobin's Q and multiple capital inputs', Cornell University Working Paper, 328.

1987. 'Tobin's Q and financial Policy', Joumal of Monetary Economics, 19:69-87.

DeAngelo. H. and Masulis. R. W. 1980a. "Optimal capital structure under corporate and personal taxation", Joumal of Financial Economics, 8:3-30.

Devereux. M. P., Keen. M. J. and F. Schiantarelli. 1989. 'Tax asymmetries, investment and financial decisions in a model with adjustment costs', mimeo, Institute for Fiscal Studies.

Easterbrook. F. H. 1984. "Two agency-cost explanations of dividends", American Economic Review, September, 74.4:650-59. 
Edwards. J. S. S. 1987. "Recent developments in the theory of corporate finance", Oxford Review of Economic Policy. and M. J. Keen. 1985. Taxes investment and Q', Review of Economic Srudies, :665-679.

Fazzari. F. M., Hubbard. R. G. and Petersen. B. C. 1988. "Financing constraints and corporate investmeat", Brookings Papers on Economic Activity, 1:141-195.

Galeotti. M and F. Schiantarelli. 1988. 'Generalised Q models for investmeat and employment', Institute for Fiscal Studies Discussion Paper, 88/13.

Gertler. M. 1988. 'Financial capacity, reliquification and production in an economy with long-term financial arrangements', mimeo. and R. G. Hubbard. 1988. 'Financial factors in business fluctuations', prepared for the Federal Reserve Bank of Kansas City's Symposium on Financial Market Volatility, August, Jackson Hole, Wy.

Greenwald. B. C. and J. E. Stiglitz. 1988. 'Financial market imperfections and business cycles', NBER, Working Paper 2494.

Hayashi. F. 1985. "Corporate finance side of the Q theory of investment", Joumal of Public Economics, 27:261-88.

and $\mathrm{T}$. Inoue. 1988. 'Implementing the $\mathrm{Q}$ theory of Investment on micro data: Japanese manufacturing 1977-1985', mimeo.

Hoshi. T., Kashyap. A., and Scharfstein. D. 1988. "Corporate structure and investment: evidence from Japanese panel data", A. P. Sloan, School of Management, Working Paper 2071-88.

Jaffee. D. M. and T. Russell. 1976. 'Imperfect information, uncertainty and credit rationing', Quarterty Joumal of Economics, November, 90:651-66.

Jensen. M. C. 1986. 'Agency costs of free cash flow, corporate finance and takeovers, American Economic Review Papers and Proceedings, May, 76. 2:323-329. and Meckling. W. H. 1977. Theory of the firm: managerial behaviour, agency costs, and ownership structure", Joumal of Financial Economics, 3:305-60. 
John. K. and Williams. J. 1985. "Dividends, dilution and taxes: a signalling equilibrium", Joumal of Finance, September, 40:1053-70.

Keen. M. J. and Schiantarelli. F. 1988. "Corporation tax asymmetries and optimal financial policy", Institute for Fiscal Studies Discussion Paper 88/2.

King. M. A. 1977. 'Public policy and the corporation', London, Chapman and Hall.

Leland. H. and D. Pyle. 1977. 'Information Asymmetries, financial structure and financial intermediaries' Joumal of Finance, 32:371-387.

Mayer. C. 1986. 'Corporation tax, finance and the cost of capital', Review of Economic Studies, 53:93-112.

1987. 'The assessment: financial systems and corporate investment', Oxford Review of Economic Policy, 3.4:i-xvi.

1988. 'New issues in corporate finance', European Economic Review, complete with vol. no $: 1167-1186$.

Myers. S. C. 1977. 'Determinants of corporate borrowing', Joumal of Financial Economics, November, 5:147-176.

and N. S. Majluf. 1984. "Corporate financing and investment decisions when firms have information that investors do not have", Joumal of Financial Economics, June, 13:187-221.

Nickell. S. J. 1981. 'Biases in dynamic models with fixed effects', Econometrica, 49:1417-1426.

Schiantarelli. F. and D. Georgoutsos. 1987. 'Monopolistic competition and the $Q$ theory of investment', European Economic Review, forthcoming.

Smith. C. W. Jr. and Warner. J. B. 1979. "On financial contracting: an analysis of bond covenants", Joumal of Financial Economics, 7:117-161.

Steigum. E. Jr. 1983. 'A financial theory of investment behaviour', Econometrica, 51:637-645.

Stiglitz. J. E. and A. Weiss. 1981. "Credit rationing in markets with imperfect information", American Economic Review, June, 71:393-410. 
Titman. S. and R. Wessels. 1988. 'The determinant of capital structure choice', The Joumal of Finance, March, 43.1:pp.1-18. 
</ref_section> 


\section{APPENDIX}

The firm maximises the market value of the shares of existing shareholders, $V_{t}$ :

$V_{t}=E, \sum_{l=0}^{\infty}\left(\frac{1}{1+\frac{R}{1-z}}\right)^{1+1}\left\{Y D_{\imath}-I_{i}^{-\gamma}\left(1+\omega_{t}\right)\right\}$

where $D_{t}$ denotes dividends, $l i$ new shares issued, $W$, the sample selection premium,

$Y=(1-m) /(1-z)(1-c)$, with $m$ denoting the tax rate on dividend, $z$ the tax rate on capital gains and $c$ the rate of imputation. $R$ is the market rate of return on equity, assumed to be constant for simplicity.

The maximisation is subject to the definition of sources and uses

$$
\begin{aligned}
& (1-\tau) P_{t}^{\prime} \Pi\left(K_{t} I_{t}\right)-A_{t}\left(I_{t}, B_{t}, L_{t}, P_{i} K_{t}^{\prime}\right)+1 i_{t}^{\prime}+B_{t-1}+L_{t}\left(1+(1-\tau) i^{L}\right) \\
& =D_{t}+p_{t} I_{t}+(1+i(1-\tau)) B_{t}+L_{t-1}
\end{aligned}
$$

where $\tau$ the corporate tax rate, $p_{1}^{y}$ the price of output, $p_{t}$ the price of investment goods, $\Pi$ real revenues net of variable costs, $K_{t}$ capital stock, $B_{t}$ debt, $L_{\imath}$ liquid assets, $i$ the rate of interest on debt and $i^{L}$ the rate of interest on liquid assets. For ease of notation we omit depreciation allowances, then are included, however, in the empirical work. $X_{t}$ is defined as

$x_{\imath}=(1-\tau) \Pi_{\imath}-(1+i(1-\tau)) B_{\imath}+\left(1+i^{L}(1-\tau)\right) A_{\imath}$

The capital accumulation equation is

$K_{\imath}=(1-\tau) K_{1-1}+I_{1}$

and the non-negativity conditions are $\gamma_{i} \geq 0$ and $D_{t} \geq 0$.

The first order conditions are: 


$$
\begin{aligned}
& \left(\gamma+\mu_{t}^{D}\right)\left[\left(1-A_{1}(t+1)(1-\tau) p_{t}^{y} \Pi_{l}(t)-P_{l}\right]+\lambda_{l}^{k}=0\right. \\
& \left(y+\mu_{t}^{D}\right)\left[\left(1-A_{K}(t)(1-\tau) p_{1}^{j} \Pi_{K}(l)-P_{t} \cdot A_{K}(t)\right]-\lambda_{t}^{k}\right. \\
& +\frac{1-\delta}{1+\frac{R}{1-z}} \lambda_{t}^{\kappa}+1=0 \\
& Y+\mu_{t}^{D}-1-\omega_{t}+\mu_{i}{ }^{T}=0 \\
& \left(Y+\mu_{t-1}^{D}\right)+\frac{\left(Y+\mu_{t-1}^{D}\right)}{1+\frac{R}{1-\ell}}\left[-\left(1-A_{B}(t+1)(1+i(1-\tau))\right.\right. \\
& \left.-t_{B}(t+1)\right]=0 \\
& \left(y+\mu_{l-1}^{D}\right)+\frac{\left(y+\mu_{t-1}^{D}\right)}{1+\frac{R}{1-z}}\left[\left(1-A_{L}(t+1)\left(1+i^{L}(1-\tau)\right)\right.\right. \\
& \left.-. t_{L}(t+1)\right]=0
\end{aligned}
$$

also:

$$
\begin{aligned}
& \left.\lambda_{l}^{B}+\left(\gamma+\mu_{l}^{D}\right)\left[\left(1-A_{X}(t)\right)(1+(1-\tau) i)+A_{B}(t)\right]\right\}=0 \\
& \left.\lambda_{l}^{l}+\left(\gamma+\mu_{l}^{D}\right)\left[\left(1-A_{X}(l)\right)\left(1+(1-\tau) i^{L}\right)+._{L}(t)\right]\right\}=0
\end{aligned}
$$

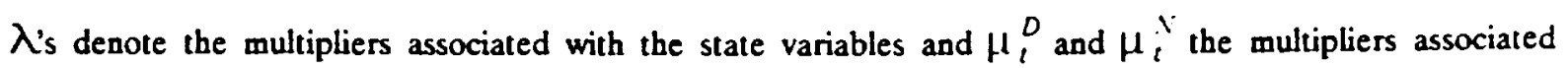
with the non-negativity condition for $D_{t}$ and $V_{l}^{-N}$. (A4) to (A10) together with the complementary slackness conditions summarise the conditions for an optimum. 
If we assume that the adjustment cost function is separable and has the form $\frac{b}{2}\left[\left(\frac{l}{h}\right)_{t}-c\right]^{2} K_{t}$, equation (A4) yields (1) in the main text when $D_{1}>0$ so that $\mu_{l}^{D}=0$.

In order to obtain the relationship between the marginal and average value of the capital stock. equation (2) in the main text, multiply (A4) by $I_{t}(A 5)$ by $K_{t},(A 6)$ by $V_{t}$, (A7) by $B_{t+1},(A B)$ by $L_{1+1},(A 9)$ by $B_{1},(A 10)$ by $L_{1}$ and add them together. Solve the resulting difference equation forward and note that (A7) and (A9) imply that $\lambda_{t-1}^{8}=-\left(Y+\mu_{t-1}^{B}\right)\left(1+\frac{R}{t-i}\right)$ and that (A8) and (A9) imply that $\lambda_{t-1}^{L}=\left(Y+\mu_{t-1}^{D}\right)\left(1+\frac{R}{1-t}\right)$ This yields equation (2) in the main text. 